\title{
Same but Different: On the Applicability of Fuel Poverty Indicators across Countries - Insights from France
}

\begin{abstract}
In 2012, the Low Income High Costs (LIHC) indicator was proposed as an alternative way of measuring fuel poverty (Hills 2012). Since its publication, the indicator has received considerable attention, not only in Great Britain, but also in other European countries. The applicability of the indicator is, however, highly contingent on detailed household and building data. This leads to the question of whether it is feasible to use the indicator in countries with less extensive available data. In this study, we test the applicability of the LIHC indicator in France, using an innovative approach to estimate energy requirements in locations with limited availability of physical building data. We show how this enables us to conveniently adapt the two most frequently used indicators to the French context (and possibly to other countries) and how to compare their results.
\end{abstract}

Keywords: LIHC indicator, $10 \%$ indicator, fuel poverty, energy poverty, France, energy requirements

\section{Introduction}

In the wake of recent transformations in European energy markets, fuel poverty has become a topic of increasing social and political interest to many member states (Bafoil et al. 2014; Boardman 2012; Bouzarovski et al. 2012; Heindl 2015; Heindl and Schuessler 2015; Kopatz et al. 2013; Tews 2013). Conventionally, fuel poverty is defined as the difficulty that households experience in coping with the cost of domestic energy. In spite of current interest in the topic, very few countries officially acknowledge the existence of fuel poverty, or systematically monitor its occurrence and evolution over time. Great Britain, a pioneer in fuel poverty research and political analysis, and France are two of the exceptions to this tendency. 
In 2009, the French government launched a fuel poverty working group to analyse the nature and extent of the phenomenon in France (De Quero and Lapostolet 2009). The working group proposed a definition of fuel poverty that was passed into law (Grenelle II) in $2010^{1}$.

Furthermore, the working group presented the first assessment of the number of French households living in fuel poverty, based on the $10 \%$ indicator proposed by Brenda Boardman in 1991 (Boardman 1991). According to this indicator, households that need to spend more than $10 \%$ of their disposable income on fuel costs in order to reach a certain level of comfort, are considered to be fuel poor. In France in 2006, this indicator found 3.4 million households $(13 \%)$ to be fuel poor.

The way the $10 \%$ indicator is used in France differs considerably from its original version, thus we refer to these two versions of the indicator as " $10 \%$ British version" and " $10 \%$ French version”. The British version uses modelled 'energy requirements' or the energy needed to attain a level of convenient domestic thermal comfort, while the French version uses real declared energy consumption. This difference has an impact on who is considered to be fuel poor, since households restricting their consumption would not be identified as fuel poor when using declared energy consumption.

In recent years, there has been increasing concern about the $10 \%$ indicator's ${ }^{2}$ adequacy in correctly depicting the fuel poverty phenomenon (Boardman 2012; Hills 2011, 2012; Moore 2012; ONPE, 2014). Alternative approaches are being discussed, including modifications to the 10\% indicator (Gawel and Bretschneider 2014; Heindl 2015; Heindl and Schuessler 2015; Hills 2011; Liddell et al. 2012; ONPE, 2014; RAPPEL, 2012) and subjective indicators (Devalière et al. 2011; Hills 2011; Waddams Price et al. 2012) as well as an approach based on a minimum income standard (Moore 2012) or yet a consensual measure (Healy and Clinch

\footnotetext{
${ }^{1}$ Loi $\mathrm{n}^{\circ} 2010-788$ du 12 juillet 2010 portant engagement national pour l'environnement (in English : Law nb. 2010-788 from the 12th of July 2010 concerning the national engagement for the environment).

${ }^{2}$ We use the term " $10 \%$ indicator" when referring to the indicator in a general way, regardless of the differences between the French and the British version.
} 
2002; Thomson and Snell 2013). Furthermore, qualitative approaches, mainly based on interviews with affected households, have been proposed as a way of assessing fuel poverty (Brunner et al. 2011; Harrington et al. 2005; Middlemiss and Gillard 2015). In 2011, the UK Department of Energy and Climate Change commissioned a review of the $10 \%$ indicator (British version), which led to a new indicator proposed by John Hills and his research team. This indicator, called Low Income High Costs (LIHC), seeks to overcome the shortcomings of the $10 \%$ indicator and incorporates relevant insights from poverty research. Recently, the LIHC indicator has received considerable attention in France and the French Fuel Poverty Observatory (ONPE) seems inclined to recommend its application to the French context (among others, see chapter 4) (ONPE 2014).

Regardless of the indicator used, one main concern is whether it is possible to correctly transfer the indicators to the French context given the data requirements they impose. It has become a convention in fuel poverty research to use data on energy requirements rather than data from real energy consumption to ensure that the households that restrict their consumption are not excluded from the population of potentially fuel poor households. In France, the precise data on building characteristics for modelling energy requirements is not yet available. Primarily, the research question we are interested in is whether it is possible to transfer fuel poverty indicators based on energy requirements, to countries with limited data availability, such as France. We present an innovative approach for modelling energy requirements using available data. Building on this, our second research interest is to carry out a case study on fuel poverty in France by applying the $10 \%$ indicator (British version) and the LIHC indicator to the French context. We concentrate on these two indicators because, to date, the $10 \%$ indicator is the most widely known and used fuel poverty indicator and because the LIHC indicator is the one that has received the most attention in the discussion on alternatives to the $10 \%$ indicator. 
The results confirm the method used and show that the two indicators differ concerning the number and type of households that are identified as being fuel poor (as has been shown for England as well).

Even though the focus of our study is on fuel poverty in France, we believe that our research yields important insights that go beyond this case study context. The method we present may be replicated in all those other countries with restricted data availability (the detailed data available in the $\mathrm{UK}$ is an exception rather than the norm $)^{3}$. We believe that research in this domain may contribute to a better understanding of fuel poverty and may thus enhance political engagement and the willingness to collect more detailed data.

Through inquiry into the way fuel poverty indicators can be used in countries with restricted data availability, our paper contributes to the literature on environmental justice and energy governance (Bazilian et al. 2014; Bickerstaff et al. 2013; Falkner 2014; Farrell and Lyons 2015; Goldthau 2014; Grösche and Schröder 2011; Laurent 2011; Liddle and Latham 2009; Preston et al. 2010; Schaffrin 2013; Schiellerup et al. 2009; Sovacool 2013; Sovacool and Dworkin 2014; Sovacool et al. 2014; Stockton and Campbell 2011; Ürge-Vorsatz and Tirado Herrero 2012; G. Walker and Day 2012; R. Walker et al. 2014). As Falkner (2014) recalls, we are today confronted with an energy trilemma, i.e. the challenge of addressing the three demands of energy security, climate change mitigation and the reduction of fuel poverty (Falkner 2014, p. 192). This poses the question of how to attain the objective of a low-carbon society while at the same time assuring that this happens in a socially balanced manner. The option of using viable indicators that allow the measurement and tracking of fuel poverty evolving over time are of crucial importance to this goal. These indicators allow evaluation of the impact of climate change policies on low-income households and to take it into account in the design of socially just policies.

\footnotetext{
${ }^{3}$ Even though the method will have to be adopted according to the available data and national specificities.
} 
The article is structured as follows: In section 2, we give a concise overview of the indicators used in this study and discuss the related proposals from the French Fuel Poverty Observatory (ONPE). In section 3, we outline our method, focusing on the approach for estimating energy requirements. Section 4 is dedicated to presenting our results and discussing our findings. The concluding fifth section summarises the objectives and the findings of the article, discusses the impact of our study on the current French debate on choosing a fuel poverty indicator, the implication of our research for other countries with restricted data and provides ideas for further research.

\section{Short description of indicators}

This section gives a short overview of the indicators presented in the paper, including those indicators proposed by the French Fuel Poverty Observatory (ONPE). The indicators have been discussed in great detail elsewhere (Boardman 1991; Hills 2011, 2012; Liddell et al. 2012). This section thus merely summarises the main characteristics of each indicator, enabling the reader to understand the description of our calculation model and the discussion of results.

\subsection{Comparison of the $10 \%$ and the LIHC indicator}

The origins of the $10 \%$ indicator (British version) date back to 1988, when British households spent on average $5 \%$ of their income on domestic energy. Twice this amount (10\%) was considered disproportionate spending (Boardman 1991; Isherwood and Hancock 1979). In addition, the three lowest income deciles effectively spent, on average, $10 \%$ of their income on domestic energy (Boardman 1991). This lead to the definition of the first, and still most widely-used, fuel poverty indicator which determines that a household is fuel poor if it needs to spend more than $10 \%$ of its income on energy services in the home. In Great Britain, the indicator operates with modelled energy bills rather than real expenditure. This accounts for the phenomena of restriction (real consumption being less than energy requirements) and 
excessive consumption (real consumption being greater than energy requirements) (Hills 2012, p. 30). To date in France, the use of real consumption data is justified by the lack of appropriate data (ONPE, 2014).

Apart from the question of whether it is still appropriate to use a fixed threshold based on obsolete data (Hills 2011, 2012; Liddell et al. 2012), one of the main criticisms of the $10 \%$ indicator relates to the way the indicator deals with income. While definitions of fuel poverty assume a relationship between low income and fuel poverty, the indicator does not provide any mechanism to exclude wealthy households. Thus, under the $10 \%$ indicator, a wealthy household can be considered fuel poor if the size of the home results in high energy requirements (Hills 2012, p. 30).

One major issue with the $10 \%$ indicator (British version) is its sensitivity to energy prices ${ }^{4}$. Fuel poverty is commonly described as the interplay between high energy prices, poor energy efficiency in housing stock and low household incomes (Boardman 2010, p. 21; Hills 2011, p. 36). A reliable indicator should correctly reflect changes in each one of these variables (Hills 2011, p. 13). The Hills report illustrates how the number of fuel poor households in Great Britain fluctuates unduly with changes in energy prices when using the $10 \%$ indicator. This masks the impact of the other two key elements of fuel poverty, namely energy efficiency and income. Furthermore, it presents fuel poverty as a cyclical problem rather than a structural one. It goes without saying that a fuel poverty indicator should respond to energy price changes. However, it seems that the $10 \%$ indicator (British version) does so in a way that yields a distorted picture of the underlying problem (Hills 2012, pp. 30-31).

\footnotetext{
${ }^{4}$ The $10 \%$ indicator (French version) is less sensitive because households may adapt their consumption to rising energy prices. This is, however, a weakness in this indicator, because households restricting their consumption can no longer be identified as fuel poor.
} 
In addition, the indicator provides information on the extent of fuel poverty, i.e. the number of persons or households affected, but not on the severity of the problem ${ }^{5}$. Therefore, it cannot account for cases in which a household's situation has improved, but still remains in fuel poverty. Political measures can thus appear poorly targeted, if they improve households' circumstances but do not enable them to cross the fuel poverty threshold (Hills 2011, p. 105). Unlike the $10 \%$ indicator that is based on an absolute threshold, the LIHC indicator proposes two relative thresholds that are dynamic over time and identifies energy poor households by their position in relation to these two thresholds. The energy cost threshold, which is defined as the median of current national energy expenses, and the income threshold which is defined as the risk of poverty line (60\% of the national median). Furthermore, each household's modelled energy costs are added to the poverty line, thus accounting for the possibility that some households at the margins of poverty can tip into fuel poverty due to their disproportionately high energy costs. The LIHC indicator identifies households with energy costs above the energy costs threshold and an income below the income threshold as fuel poor (Hills 2011, pp. 135-137). Furthermore, the fuel poverty gap, defined as the difference between a household's energy costs and the energy cost threshold, allows the depth of fuel poverty to be assessed. The fuel poverty gap illustrates the amount by which the energy costs of fuel poor households exceed what is expected reasonable spending (the energy cost threshold) (Hills 2011, p. 21; 2012, pp. 11-12). As an aggregated measure, the fuel poverty gap yields an estimate of the "cumulated social costs" of the problem (ONPE, 2014, p. 28). By using relative thresholds, the impact of the energy price is attenuated. Consequently, there is less fluctuation in the number of households identified as living in fuel poverty (Hills 2012, p. 34). This reflects the notion that fuel poverty is not determined exclusively by energy prices but rather by the interplay of several elements, of which the price of energy is just one,

\footnotetext{
${ }^{5}$ However, the distribution of households' energy burden (ratio energy requirements/income) provides an idea of how many households face a more or less severe situation. In addition, tracing a household's situation over time provides a further measure of affectedness.
} 
alongside energy efficiency and income. The LIHC indicator has a tendency to yield a more stable measurement of fuel poverty, nonetheless the impact of energy price changes are still captured by the fuel poverty gap. This illustrates the effect of increases in energy prices on those identified as fuel poor (Hills 2012, p. 34).

Compared to the $10 \%$ indicator (British version), the variables used for the LIHC indicator are slightly modified by deducting housing costs from income as well as the equivalisation of income and energy costs (Hills 2011, p. 137; 2012, pp. 50-53).

The deduction of housing costs from income is justified by the specificity of housing costs, compared to other household expenses. Prices for the majority of vital goods and services remain mostly steady throughout the country, however, rents and real estate prices vary considerably by location and occupancy. Therefore, an after housing costs income measure (AHC income) is used to provide a more reliable assessment of domestic disposable income (Hills 2011, p. 8).

Income equivalisation is a common practice in poverty research and allows for the appreciation of incomes in the light of living standards. In order to equivalise income, weights are assigned to each household according to the number of householders and their age. For two households with an equal cash income but a different household structure, the equivalised income differs. For example, equivalised income would be lower for a couple with two children than for a single person household (Hills 2011, p. 138).

In addition, an approach for the equivalisation of energy requirements is presented in the Hills review. The rationale for equivalising energy requirements is that it allows for the understanding of what 'it is 'reasonable' or 'unreasonable' for each household to spend on energy given their household composition" (Hills 2012, p. 51). This approach allows for the comparison of energy costs for different household types and for the same energy costs threshold to be used for all households. However, given the particularities of energy 
consumption, a specific equivalisation scale based on empirical data is conceived, rather than using the income scale (for more detail see Hills 2012, p. 52).

Most of the criticism of the LIHC indicator is about its complexity and lack of transparency (Boardman 2012; Moore 2011). The most frequently criticised elements are the equivalisation of energy costs, the way in which the energy cost threshold is determined, and the use of relative thresholds. While equivalising income is a common practice in poverty research, the equivalisation of energy costs is not yet an established approach (Moore 2011). Furthermore, the use of the national median in order to determine the energy cost threshold has been criticised for being arbitrary and for excluding a large number of households with high energy costs (Boardman 2012; Moore 2011). More generally, the use of the median as a measure to determine the thresholds implies that it becomes extremely difficult to eliminate fuel poverty, since there will always be $50 \%$ of the population above and below the threshold (Moore 2012).

\subsection{The indicator proposed by the French Fuel Poverty Observatory}

As mentioned above, in its recent publication, the French Fuel Poverty Observatory (ONPE) discussed the possibility of applying the LIHC indicator to the French context. Several modifications to the original version are proposed, partly due to lack of data. The proposed indicator would be based on real energy consumption, since, according to ONPE, normative energy consumption cannot be modeled with the data currently available in France.

Furthermore, ONPE proposes two ways to adjust households' energy expenses. The first option is the use of an equivalisation scale that takes account of household size and composition (we refer to this as $\mathrm{LIHC} / \mathrm{UC}^{6}$ ). However, in its report, ONPE does not specify which kind of equivalisation scale is used. The second option is to adjust energy expenses by square meter of living space, an approach which is justified by the fact that size of living

\footnotetext{
${ }^{6} \mathrm{UC}$ stands for unit of consumption.
} 
space has a greater impact on energy costs than the number of household members (we refer to this as $\left.\mathrm{LIHC} / \mathrm{m}^{2}\right)$ (ONPE, 2014, p. 26).

As far as income is concerned, the income threshold proposed by ONPE differs from the original version insofar as the households' energy costs are not added to the baseline threshold (60\% of national median income). This omission is neither explained further nor justified (ONPE, 2014, p. 26).

\section{Method}

\subsection{Databases}

In England, the English Housing Survey (EHS) provides all necessary data to estimate fuel poverty when using the two indicators described above. This survey is carried out annually; it consists of an interview and a physical survey. In 2010-2011, approximately 16,000 households were interviewed, and a physical survey was carried out on about half of the dwellings.

In France, the most comparable data is provided by the national dwelling survey (Enquête Nationale Logement, ENL). This survey contains information on income, rents and mortgage reimbursements. Furthermore, it yields some, but not all, data on dwelling characteristics, which are necessary to calculate energy requirements. The survey is carried out every 5 to 6 years on a sample size of about 50,000 dwellings in metropolitan France. The most recent data currently available was collected in 2006 . The data collected in the 2013 survey, which was only available in 2015, could not yet been used for the calculations presented in this article.

\subsection{Income}

As has been mentioned in Section 2.1, each indicator uses a different income measure. The $10 \%$ indicator is based on a measurement of full income. This means that the sum of net 
income from all household members is used, including benefit payments (from private sources, state benefits and savings) (for more detail see DECC, 2010, chapter 6). The only difference between the two versions of the indicator lies in the deduction of council taxes from full income in the British version.

The income measure used for the LIHC indicator is based on this full income measure.

However, housing costs are deducted from income, leading to an after housing costs (AHC) income, which is further adjusted for household size and composition.

The housing costs that are deducted from this full income are limited to rent and mortgage repayments for simplification. This means that other costs related to housing such as water rates or service charges are not considered (Hills 2012, p. 111). The AHC modified OECD ${ }^{7}$ equivalisation scale is used to obtain equivalised AHC incomes (Hills 2011, p. 172).

Our primary database (ENL) provides all the necessary information to determine household before housing costs (BHC) and after housing costs (AHC) income in France. Some benefits that exist in England, for example income support for mortgage interest, have no French equivalent and therefore cannot be considered in our calculation. Furthermore, a measure specifically designed for supporting households in fuel poverty, the "Winter Fuel Payment", is added to income in the British model. In France, there is a similar political measure targeted at fuel poor households. Households within a certain income class are entitled to reduced energy tariffs. In 2006, the year our data was collected, the only tariff in place was the social tariff or electricity (implemented in 2004). The social tariff for gas was not implemented until $2008^{9}$. However, we believe that the social tariff for electricity cannot be directly compared to Winter Fuel Payments since they are a year-round benefit and not only applicable when

\footnotetext{
${ }^{7}$ Organisation for Economic Co-operation and Development

${ }^{8}$ This scale attributes a value of 0.58 to the first adult in the household, 0.42 to all other adults and children aged 14 years and over and 0.2 to children under the age of 14 .

${ }^{9}$ Tarif de Première Nécessité (TPN) for electricity, and Tarif Spécial de Solidarité (TSS) for gas. Since 2012, the social tariffs have been automatically attributed. Before, the number of beneficiaries was rather low and thus the impact on energy bills rather limited.
} 
temperature falls below a certain level, as is the case for Winter Fuel Payments. Furthermore, strictly speaking, social tariffs have an impact on energy bills rather than on income. This means that instead of being considered a benefit added to income, they would have to be considered in the energy costs model. Therefore, in order to assure comparability between our results and those obtained in England, social tariffs were not considered in our calculations.

\subsection{Energy requirements}

\subsubsection{The basic model}

In Great Britain, energy requirements are modelled using BREDEM (BRE Domestic Energy Model). BREDEM plays a central role as part of the government's methodology for assessing the energy performance of domestic buildings ${ }^{10}$. The model takes into account space and water heating, cooking, lighting and electrical appliances. With regards to modelling energy requirements for fuel poverty statistics, the calculations are based on information retrieved from the EHS on buildings' physical characteristics (type of walls, insulation, fuels used), heating systems, controls and location as well as householders' presence at home (Anderson et al. 2002, pp. 1-2; Hills 2011, p. 98).

Since limited data is available in France, we have developed an innovative approach for calculating energy requirements. This approach is based on the 3CL-method (MECSL, 2006) ${ }^{11}$, which is comparable to the British SAP procedure ${ }^{12} .3 \mathrm{CL}$ is a simplified method of calculating energy requirements and is used in France to issue building Energy Performance Certificates. Based on the French building regulation adopted in 1988, the 3CL method was originally conceived for concrete applications, i.e. on-site diagnosis, where the necessary

\footnotetext{
${ }^{10}$ https://www.gov.uk/standard-assessment-procedure

11 3CL stands for "Calcul des consommations conventionnelles des logements" which in English means "Calculation of conventional consumptions of dwellings".

${ }^{12}$ Standard Assessment Procedure for Energy Rating of Dwellings. Simplified procedure based on BREDEM.
} 
information on building morphology, the level of insulation, the efficiency of heating systems and climatic conditions could be readily assessed.

We use the method to estimate the energy requirements for each dwelling in ENL database (ENL 2006). This database provides some, but not all, necessary input data. For example, for buildings built after the first thermal regulations in 1975, levels of insulation can be estimated by regulation standards. For older and refurbished buildings only qualitative information on the level of refurbishment is available (roof insulation and window replacement) ${ }^{13}$. This has to be transformed into quantitative data. The information is then used to determine the proportion of refurbished buildings as well as the quality of insulation. Geometrical and morphological aspects such as compactness, common walls, number of floors, position in the building, are also derived from the ENL database.

Using this approach we are able to assign, for each dwelling, the corresponding heat transfer coefficient (U-value) for all elements of the building envelope. The 3CL algorithm allows the calculation of the useful energy requirement, adding heat transfer through the envelope, ventilation losses, and deducting solar gains for each dwelling. Meteorological data (heating degree days and solar radiation) are defined at the French department level.

The ENL database provides information on the type of energy for the main system and for complementary systems as well as the type of system (individual or collective) for space and water heating systems. The age or efficiency of the system is not provided. However, 3CL indicates efficiency values according to the age, energy and type (individual or collective) of the system. We attribute this information to the ENL database via a proxy: If the building has been constructed within the last 15 years, we use the age of the building as an indicator for the age of the system. If the building is older, we randomly assign the information.

\footnotetext{
${ }^{13}$ In the ENL survey, respondents are asked, for instance: "What is the level of roof insulation: good level $<10$ years, good level $>=10$ years, insufficient, no insulation?"
} 
To assess energy consumption for hot water, a basic requirement in terms of useful energy requirement for hot water per inhabitant is used. This requirement is modulated according the temperature of the cold water supply in each location, and then converted into final energy regarding the system efficiency (generation, distribution and storage efficiencies). Note that we do not use the 3CL method for the hot water requirement, which is based on the dwelling's living area and is not designed to represent a specific household's requirements. In order to estimate energy consumption for lighting and appliances, we use consumption ratios $\left(\mathrm{kWh} / \mathrm{m}^{2}\right)$ from the Ceren database (Ceren, 2011).

At this stage, energy requirements are based on the physical characteristics of each dwelling and the standard 3CL heating regime, but it does not take into account household composition and living circumstances. In order to take this information into account, energy requirements are adjusted according to different heating regimes and (for the LIHC indicator) equivalised according to household size and composition (Anderson et al. 2002, pp. 7-8; Hills 2012, pp. 50-53).

\subsubsection{Adjustment of energy requirements according to household characteristics}

The households' energy requirements do not only depend on the physical characteristics of the dwelling and the climate zone but also on occupancy and heating patterns. For example, people with full-time jobs spend less time at home than unemployed people or pensioners. Furthermore, householders in an over-dimensioned dwelling, e.g. couples with children who have left home, will most probably not heat the unoccupied parts of their dwelling. For this reason, fuel poverty calculation in Great Britain includes heating regimes (Hills 2011, p. 99). Table 1 gives an overview of these regimes. The heating regimes determine if the dwelling is heated only for some hours ("standard" and "partial standard") or all day ("full" and "partial full") and if part ("partial" and "partial full") or the entire dwelling ("standard" and "full") is 
heated. A combination of these parameters yields four heating regimes, which are further differentiated by weekdays and weekends (see also Anderson et al. 2002, p. 8).

Table 1: Simplified representation of heating regimes

\begin{tabular}{|l|l|l|l|l|}
\cline { 2 - 6 } \multicolumn{1}{c|}{} & \multicolumn{1}{c|}{ Standard } & \multicolumn{1}{c|}{ Full } & Partial Standard & \multicolumn{1}{c|}{ Partial Full } \\
\hline $\begin{array}{l}\text { Heating pattern } \\
\text { - Weekday } \\
\text { - Weekend }\end{array}$ & $\begin{array}{l}9 \text { hours } \\
16 \text { hours }\end{array}$ & $\begin{array}{l}16 \text { hours } \\
16 \text { hours }\end{array}$ & $\begin{array}{l}\text { 9 hours } \\
16 \text { hours }\end{array}$ & $\begin{array}{l}16 \text { hours } \\
16 \text { hours }\end{array}$ \\
\hline \hline Heating extent & Whole house & Whole house & Half house & Half house \\
\hline $\begin{array}{l}\text { Demand temperature } \\
\text { - Primary living area } \\
\bullet \text { Secondary living area }\end{array}$ & $\begin{array}{l}21^{\circ} \mathrm{C} \\
18^{\circ} \mathrm{C}\end{array}$ & $\begin{array}{l}21^{\circ} \mathrm{C} \\
18^{\circ} \mathrm{C}\end{array}$ & $\begin{array}{l}21^{\circ} \mathrm{C} \\
18^{\circ} \mathrm{C}\end{array}$ & $21^{\circ} \mathrm{C}$ \\
\hline $\begin{array}{l}\text { Example } \\
\text { Employed } \\
\text { couple living }\end{array}$ & $\begin{array}{l}\text { Pensioner } \\
\text { living in a } \\
\text { one-bedroom } \\
\text { bungalow }\end{array}$ & $\begin{array}{l}\text { Employed couple } \\
\text { with one child, } \\
\text { living in a three- } \\
\text { bedroom home }\end{array}$ & $\begin{array}{l}\text { Unemployed single } \\
\text { person living in a } \\
\text { large two-bedroom } \\
\text { home }\end{array}$ \\
\hline
\end{tabular}

Source: Hills (2011, p. 99), based on DECC.

To calculate heating regimes, information on the surface of the primary living area (zone 1) and the secondary living area (zone 2) for each household is needed as the assigned temperature differs for each area. Initially, the two areas are calculated using a coefficient provided by BRE (2011, p. 126). On this basis, it is possible to calculate the standard and full heating regimes. In the second step, to calculate partial heating regimes, we use a variable for under-occupancy, available from our primary database. In the case of under-occupancy, we assume that only half of zone 2 is heated (DECC 2010, p. 31; Hills 2011, p. 99) ${ }^{14}$. Finally, we use different coefficients to assign the demand temperature according to the time spent at home (heating pattern) and the extent of heating in the home (heating extent).

For both indicators, the calculation model described above is the same. In addition, the LIHC indicator operates with equivalised energy requirements, i.e. that energy requirements are

\footnotetext{
${ }^{14}$ Here our approach differs slightly from the one proposed by the LIHC indicator. Instead of using the ratio proposed by the Fuel Poverty Methodology Handbook (as is done for the LIHC indicator), we determine underoccupancy according to the official definition used in France by the French National Institute for Statistics (INSEE) by applying the variable on under-occupancy provided by our primary database. Since the living area values thus obtained differ from the ones found in Great Britain, we only divide the heated area in zone 2 by two, instead of dividing the total heated area by two.
} 
adjusted according to household size and composition (Hills 2012, pp. 50-53; for criticism on this approach see Moore 2011). As has been mentioned in Section 2.1, a specific energy costs equivalisation scale has to be developed that will differ from the one used for income (for more detail see Hills 2012, p. 52). The equivalisation scale developed for France yields the factors outlined in table 2 .

Table 2: Energy cost equivalisation scale

\begin{tabular}{|c|c|c|c|c|}
\hline $\begin{array}{c}\text { Couple with } \\
\text { dependent } \\
\text { children }\end{array}$ & $\begin{array}{c}\text { Couple without } \\
\text { dependent } \\
\text { children }\end{array}$ & Single parent & Single person & $\begin{array}{c}\text { Other multi- } \\
\text { person household }\end{array}$ \\
\hline 1.07 & 1 & 0.79 & 0.74 & 0.98 \\
\hline
\end{tabular}

Source: authors, based on Hills (2012, pp. 51-53).

Table 3 gives an overview of the different approaches for calculating income and energy costs for each indicator.

Table 3: Comparison of calculation approaches used for each indicator

\begin{tabular}{|l|l|l|l|}
\cline { 2 - 4 } \multicolumn{1}{c|}{} & $\mathbf{1 0 \%}$ French version & $\mathbf{1 0 \%}$ British version & \multicolumn{1}{c|}{ LIHC } \\
\hline Income & $\begin{array}{l}\text { Full income: Net income } \\
\text { from all household } \\
\text { members, including } \\
\text { benefit payments }\end{array}$ & $\begin{array}{l}\text { Before housing costs } \\
\text { (BHC) income: } \\
\text { Full income minus } \\
\text { council taxes }\end{array}$ & $\begin{array}{l}\text { After housing costs } \\
\text { (AHC) income: BHC } \\
\text { minus housing costs + } \\
\text { equivalisation with AHC } \\
\text { equivalisation scale }\end{array}$ \\
\hline Energy costs & $\begin{array}{l}\text { Real declared energy } \\
\text { consumption }\end{array}$ & $\begin{array}{l}\text { Modelled energy } \\
\text { requirements }\end{array}$ & $\begin{array}{l}\text { Modelled energy } \\
\text { requirements } \\
\text { + equivalisation with } \\
\text { energy costs } \\
\text { equivalisation scale }\end{array}$ \\
\hline
\end{tabular}

Source: authors

\subsection{Energy prices}

In France, energy prices are still partly regulated by government, which means that tariffs are fairly homogenous throughout the country. However, households can choose tariffs that differ with regard to electric power and peak or off-peak consumption. We develop a scheme based 
on combinations of these options. The corresponding tariffs are taken from the Pégase database (SOeS 2014). We take average prices for 2005 and 2006 in order to account for the fact that data for our primary database was collected in 2006, but answers are likely to partially reflect the respondents' living conditions in 2005.

For electricity and gas, we adapt the tariff to the level of consumption according to the examples provided in Pégase. These rely on the size of the dwelling, the electric power option chosen and consumption during peak and off-peak periods. For heating oil, gas in cylinders, district heating and wood, a single tariff is used. Table 4 gives an overview of the types and the respective tariffs.

Table 4: Energy tariffs in 2006

\begin{tabular}{|c|c|c|}
\hline & $\begin{array}{l}\text { Tariff, fixed part } \\
\text { (c€/year) }\end{array}$ & $\begin{array}{l}\text { Tariff, variable } \\
\text { part }(c € / k W h)\end{array}$ \\
\hline $\begin{array}{l}\text { Electricity (power option; consumption threshold) } \\
\text { - } 3 \mathrm{kVA} \text { basic tariff ; < } 1.5 \mathrm{MWh} / \text { year } \\
\text { - } 6 \mathrm{kVA} \text { basic tariff ; < } 2.5 \mathrm{MWh} / \text { year } \\
\text { - } 6 \mathrm{kVA} \text {, peak/off-peak tariff (assumption: } 35 \% \\
\text { off-peak consumption) ; <5 MWh/year } \\
\text { - } 9 \mathrm{kVA} \text {, peak/off-peak tariff (assumption: } 35 \% \\
\text { off-peak consumption); < } 10 \mathrm{MWh} / \text { year } \\
\text { - } 12 \mathrm{kVA} \text {, peak/off-peak tariff (assumption: } 35 \% \\
\text { off-peak consumption); } \geq 10 \mathrm{MWh} / \text { year }\end{array}$ & $\begin{array}{l}61 \\
105 \\
189 \\
273\end{array}$ & $\begin{array}{l}12.9 \\
10.6 \\
10.6 \text { (peak) / } 0.65 \\
\text { (off-peak) } \\
10.6 \text { (peak) / } 0.65 \\
\text { (off-peak) } \\
10.6 \text { (peak) / } 0.65 \\
\text { (off-peak) }\end{array}$ \\
\hline $\begin{array}{l}\text { Gas (power option; consumption threshold) } \\
\text { - basic tariff ; < } 1 \mathrm{MWh} / \text { year } \\
\text { - B0 tariff ; < } 5 \mathrm{MWh} / \text { year } \\
\text { - B1 tariff } ;<40 \mathrm{MWh} / \text { year } \\
\text { - B2I tariff } ; \geq 40 \mathrm{MWh} / \text { year } \\
\end{array}$ & $\begin{array}{l}25 \\
36 \\
125 \\
188 \\
\end{array}$ & $\begin{array}{l}0.67 \\
0.55 \\
0.38 \\
0.37 \\
\end{array}$ \\
\hline $\begin{array}{l}\text { Heating oil } \\
\bullet \text { Standard value }\end{array}$ & & 0.62 \\
\hline $\begin{array}{c}\text { Gas in cylinders } \\
\bullet \text { Standard value } \\
\end{array}$ & & 10.1 \\
\hline $\begin{array}{c}\text { District heating } \\
\text { • Standard value } \\
\end{array}$ & & 0.57 \\
\hline Wood & & 0.32 \\
\hline
\end{tabular}

Source: authors, based on SOeS (2014). 


\section{Results and discussion}

This section presents the results for the case study in which we apply the indicators to the French context. Furthermore, we compare our results for the LIHC indicator to those obtained by the French Fuel Poverty Observatory (ONPE). In addition, even though the available data does not allow to determine the current state of fuel poverty in France, we can estimate its extent and depth by using current energy prices (an average of 2012 and 2013 prices). In a second step, we show how the distribution of household characteristics differs according to each indicator.

Using the most recent available data, ENL 2006, we find that $13 \%$ of households are fuel poor according to the French version of the $10 \%$ indicator. As a reminder, to date, in France the $10 \%$ indicator (French version) is calculated using households' real declared energy costs and net declared income. This result corresponds to the one published in the first official document that quantified fuel poverty in France (De Quero and Lapostolet 2009). When using the original version of the $10 \%$ indicator $^{15}$ (British version), $11 \%$ of the French population is found to be in fuel poverty in 2006. The LIHC indicator, on the other hand, identifies $10 \%$ of households to be affected by fuel poverty, with a fuel poverty gap of 1.4 billion euros, i.e. an average gap of about 555 euros per fuel poor household.

As has been mentioned before, the French Fuel Poverty Observatory (ONPE) uses two alternative measures of the LIHC indicator: one in which energy costs are equivalised for household size and composition (LIHC/UC) and one that adjusts energy costs to living space $\left(\mathrm{LIHC} / \mathrm{m}^{2}\right)$. The main difference between our calculation and the ones carried out by ONPE is the way in which energy consumption is addressed. Whereas our calculation is based on modelled energy requirements, ONPE uses real declared energy consumption. The results presented in its report suggest that in 2006, 13\% of French households are found to be fuel

\footnotetext{
${ }^{15}$ This implies using normative modelled energy consumption and an income measure which deduces council taxes from net income.
} 
poor according to the $\mathrm{LIHC} / \mathrm{m}^{2}$ indicator and $10.3 \%$ according to the $\mathrm{LIHC} / \mathrm{UC}$ indicator. The fuel poverty gaps amount to 1.7 and 1.2 billion respectively, i.e. 507 and 430 euros on average for each affected household (ONPE 2014, p. 39).

Even though there is no current data available, we replicate the calculation using current energy prices. This yields an estimation of how fuel poverty would have evolved given today's energy prices, all other things being equal. Income has remained stable in France over recent years, both in absolute terms and across income deciles (Insee 2014), and this might serve as a justification for using this approach. However, the results are merely meant to be indicative. According to the $10 \%$ indicator (British version) in 2013, $19 \%$ of the French population would be considered to be fuel poor, while the LIHC indicator identifies only $10 \%$. However, as expected, the fuel poverty gap increases to 2.3 billion euros or about 850 euros per fuel poor household.

Table 5 summarises these results and figure 1 illustrates the effects of price increases on the LIHC indicator.

Table 5: Overview of the results obtained by different indicators.

\begin{tabular}{|c|c|c|c|c|c|c|c|}
\hline & \multicolumn{3}{|c|}{2006} & \multirow{3}{*}{$\begin{array}{c}2013 \\
10 \% \\
\text { (British } \\
\text { version) }\end{array}$} & \multicolumn{3}{|c|}{2006} \\
\hline & \multirow{2}{*}{$\begin{array}{c}10 \% \\
\text { (French } \\
\text { version) }\end{array}$} & \multirow{2}{*}{$\begin{array}{c}10 \% \\
\text { (British } \\
\text { version) }\end{array}$} & \multirow[t]{2}{*}{ LIHC } & & \multirow[t]{2}{*}{ LIHC } & \multicolumn{2}{|c|}{ ONPE } \\
\hline & & & & & & $\mathrm{LIHC} / \mathrm{m}^{2}$ & LIHC/UC \\
\hline $\begin{array}{l}\text { Households in } \\
\text { fuel poverty } \\
\text { - Total } \\
\text { (millions) } \\
\text { - Percentage }\end{array}$ & $\begin{array}{l}3.5 \\
13 \%\end{array}$ & $\begin{array}{l}2.9 \\
11 \%\end{array}$ & $\begin{array}{l}2.5 \\
10 \%\end{array}$ & $\begin{array}{l}5.1 \\
19 \%\end{array}$ & $\begin{array}{l}2.8 \\
10 \%\end{array}$ & $\begin{array}{l}3.4 \\
13 \%\end{array}$ & $\begin{array}{l}2.7 \\
10.3 \%\end{array}$ \\
\hline $\begin{array}{l}\text { Fuel poverty } \\
\text { gap } \\
\text { - Total } \\
\text { (billion } \\
\text { euros) }\end{array}$ & & & 1.4 & & 2.3 & 1.7 & 1.2 \\
\hline
\end{tabular}




\begin{tabular}{|l|l|l|l|l|l|l|}
\hline $\begin{array}{c}- \text { Average } \\
\text { (euros) }\end{array}$ & & 555 & & 850 & 507 & 430 \\
\hline
\end{tabular}

Source: own calculation and ONPE (2014).

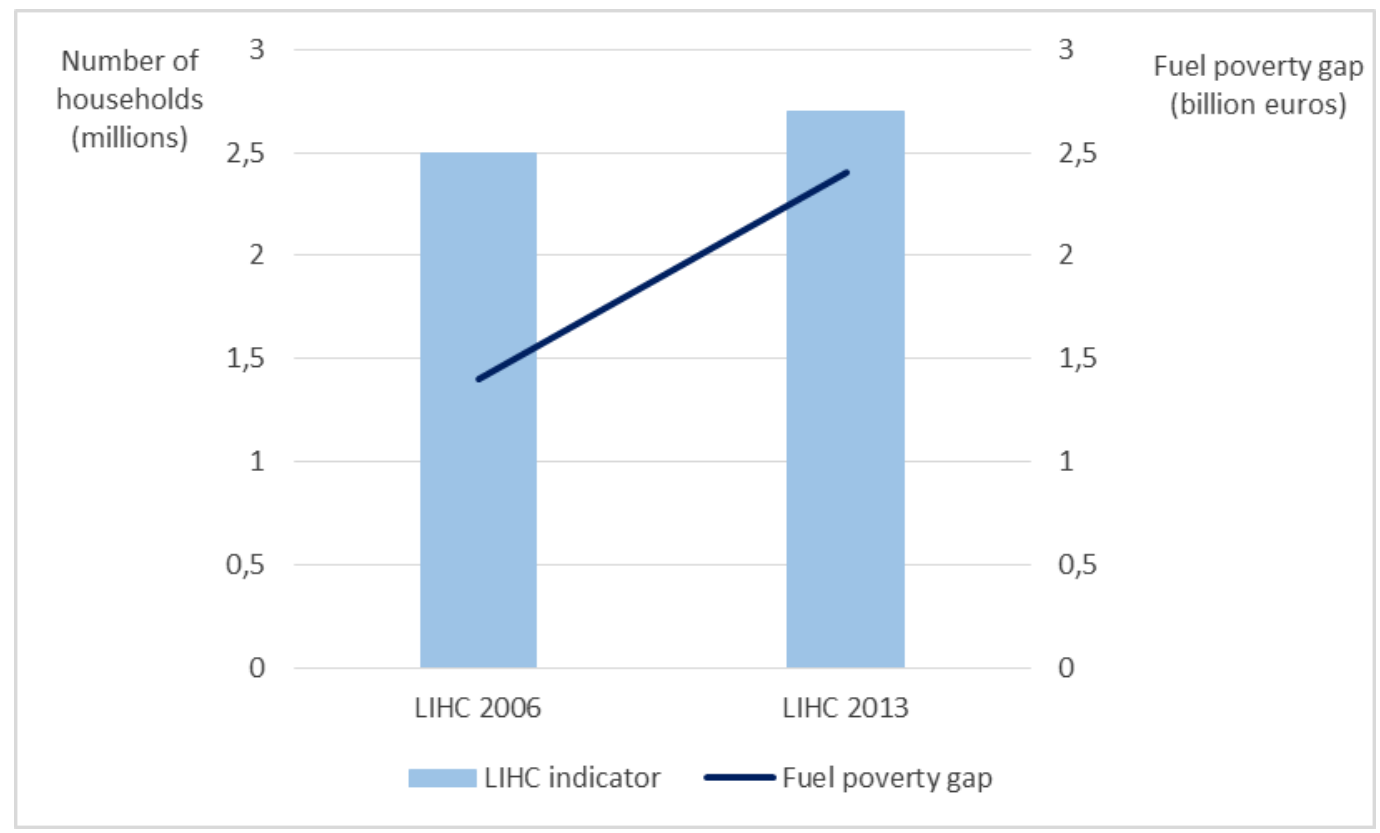

Figure 1: The impact of price increases on the LIHC measure. Source: authors, based on Hills (2011, 2012).

The results presented so far indicate that each indicator produces different results for the number of households in fuel poverty. However, as illustrated in figure 2, the distinction goes beyond the mere quantification of fuel poor households. The households identified also differ qualitatively from one indicator to another. Figure 2 depicts all households found to be fuel poor by the LIHC indicator and/or the $10 \%$ indicator (French version), based on real declared energy consumption. Households in the lower left area of the graph are those considered to be fuel poor under the LIHC indicator. Black dots represent households that are fuel poor under the $10 \%$ indicator whereas white dots represent households that are not fuel poor under the $10 \%$ indicator. The figure shows that a considerable number of households in fuel poverty according to the $10 \%$ indicator are not considered to be so according to the LIHC indicator (the black dots outside the lower left area), either because their income is too high or their 
energy costs too low to cross the respective threshold. In contrast, quite a number of

households that are not considered to be in fuel poverty under the $10 \%$ indicator are found to be so by the LIHC indicator (the white dots inside the lower left area). This can be explained by the fact that incomes and energy bills are adjusted for household size and composition under the LIHC indicator. We also have to keep in mind that each indicator uses a different approach to determine energy costs and income, which accounts for part of the difference.

Altogether, only $35 \%$ of households found to be in fuel poverty are identified as such by both indicators.

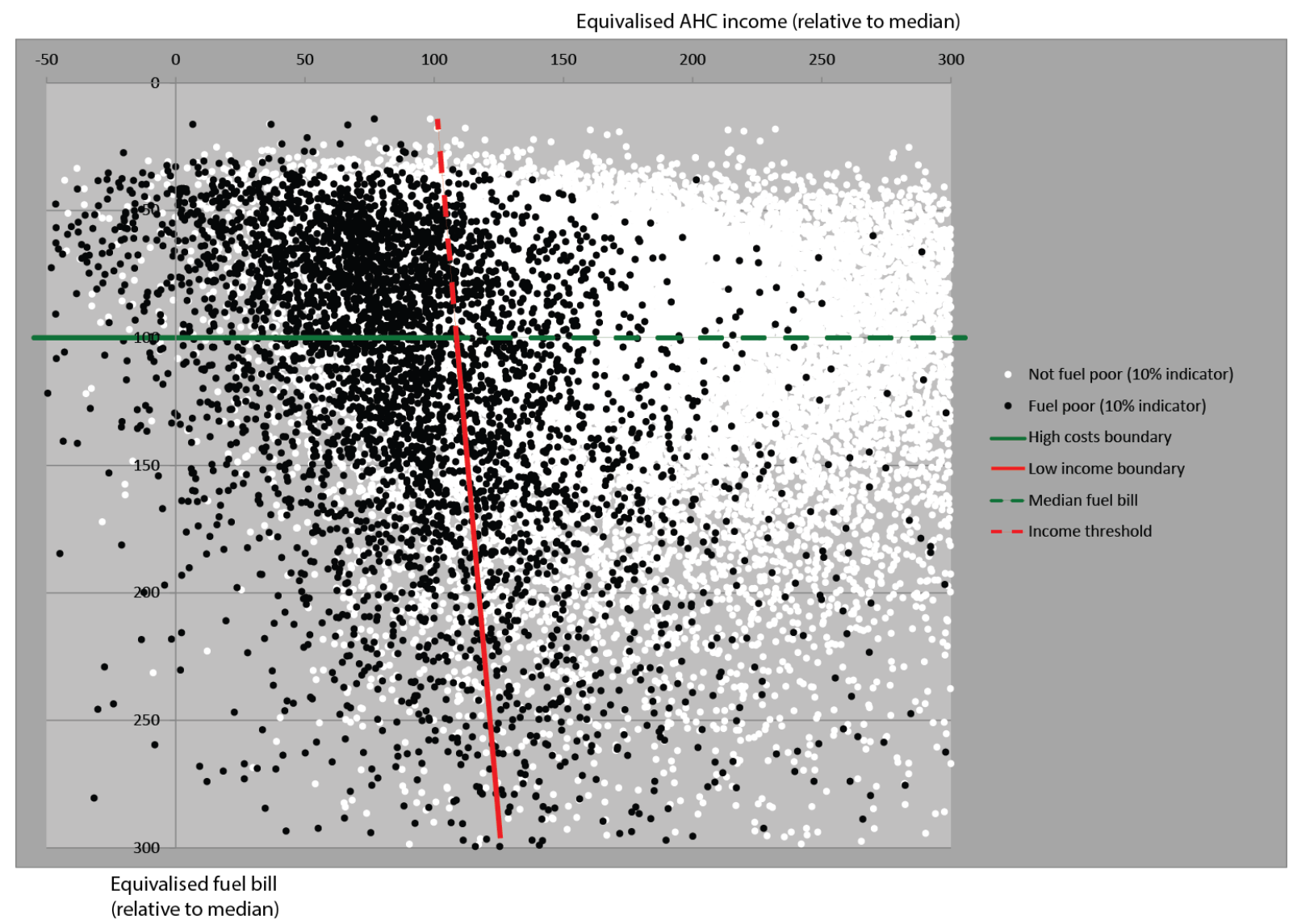

Figure 2: Households classed as fuel poor under the $10 \%$ indicator (French version) and the LIHC indicator, 2006. Source: own calculation, illustration based on Hills (2011, p. 142).

Fine-grained analyses reveal that the indicators differ in the way certain household characteristics are captured (such as income, family type and occupancy status) but less so on others (such as energy type or year of construction of the building). The following figures 
illustrate the distribution of the variables through which we observed divergences. In order to assure better legibility of the results, we limit the comparison to our own results obtained for 2006.

Figure 3 shows the representation of income deciles by the two versions of the $10 \%$ indicator (French and British versions) and the LIHC indicator. The last column (total) indicates the distribution of income deciles over the whole population. While the two versions of the $10 \%$ indicator only vary slightly, the contrast is much more pronounced when compared to the LIHC indicator. More or less $70 \%$ of households found to be in fuel poverty with the $10 \%$ indicators belong to the three most modest income deciles, whereas under the LIHC, the proportion amounts to about $85 \%$. The fact that the LIHC indicator finds fewer households in higher income classes to be fuel poor is due to the fact that the income threshold introduces a cut-off point for the exclusion of wealthy households.

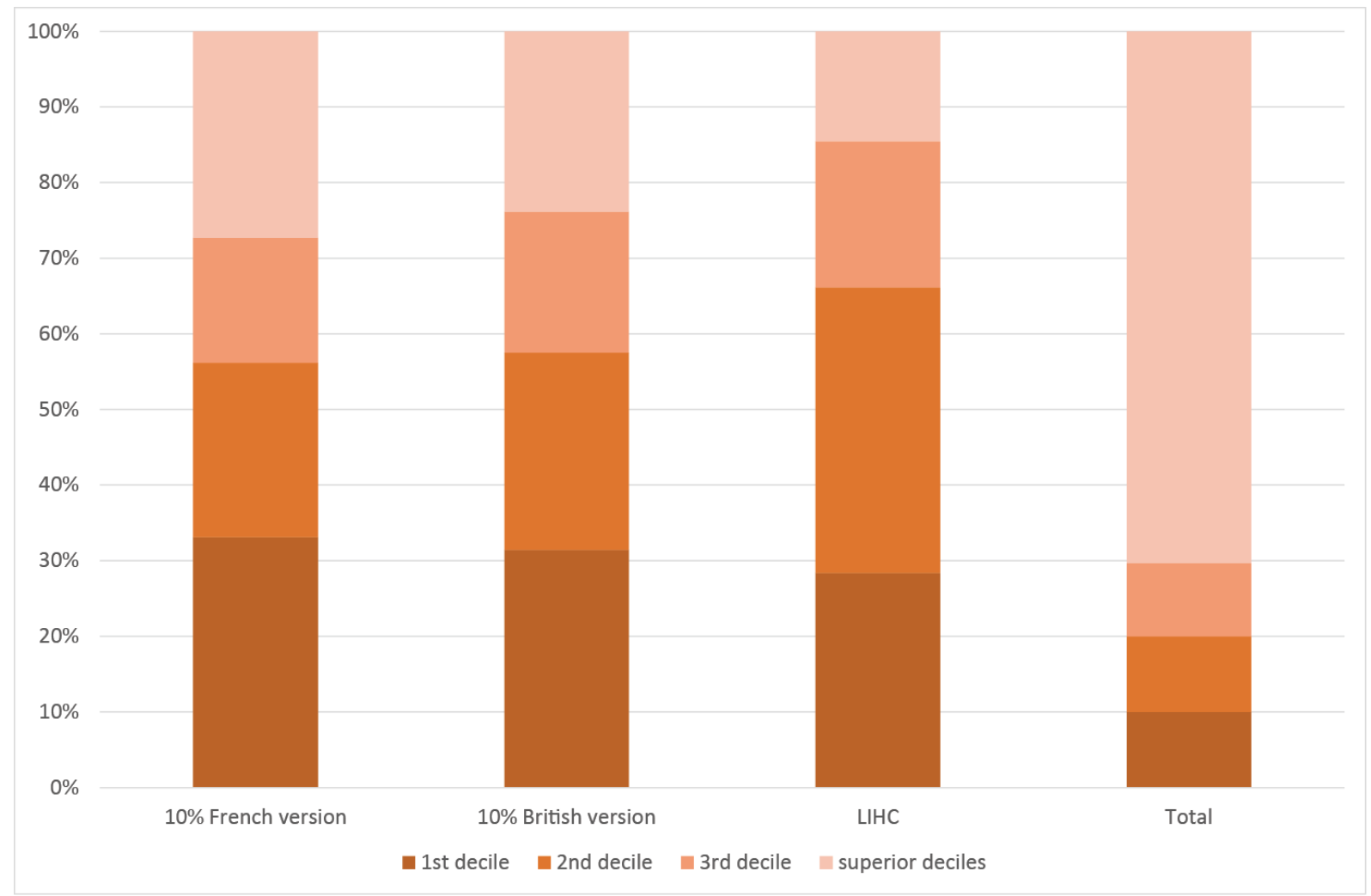

Figure 3: Representation by income decile. Source: authors. 
In figure 4, the effect of income equivalisation according to household type and composition becomes apparent. When compared to both versions of the $10 \%$ indicator, the LIHC indicator identifies more couples with children and single parents to be living in fuel poverty. Due to equivalisation, a lower income is attributed to larger households than to smaller ones, even when their real cash income is exactly the same.

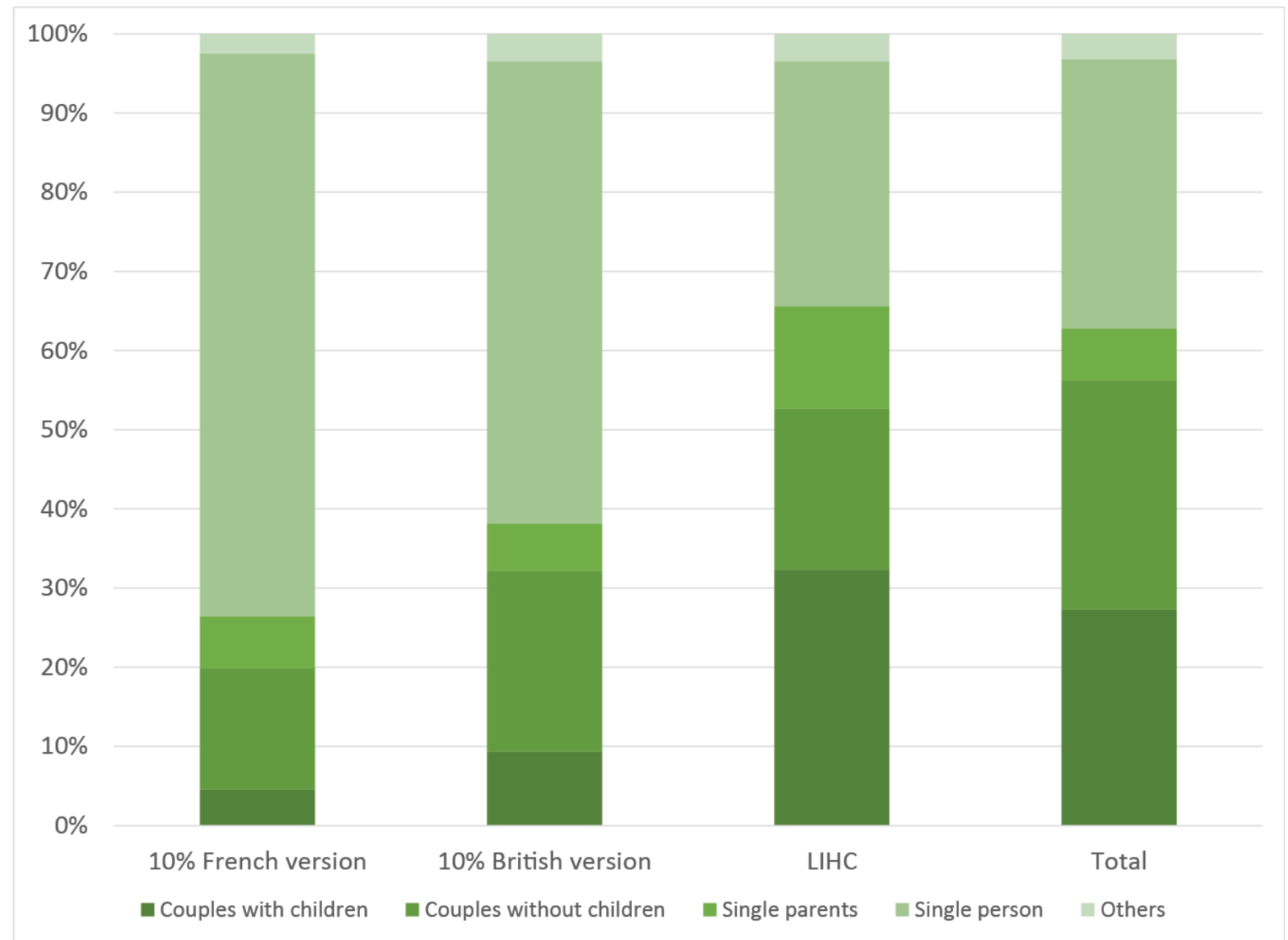

Figure 4: Representation by family type. Source: authors.

Figure 5 illustrates another specificity of the LIHC indicator: Since housing costs are taken into account during income calculation, fewer property owners who own their property outright are found to be in fuel poverty, compared to tenants and owners who are assuming ownership. Under the LIHC indicator, the disposable income of owners is considered to be higher than the income of tenants or homeowners with a mortgage, since they do not have expenses for rent or loan repayments. 


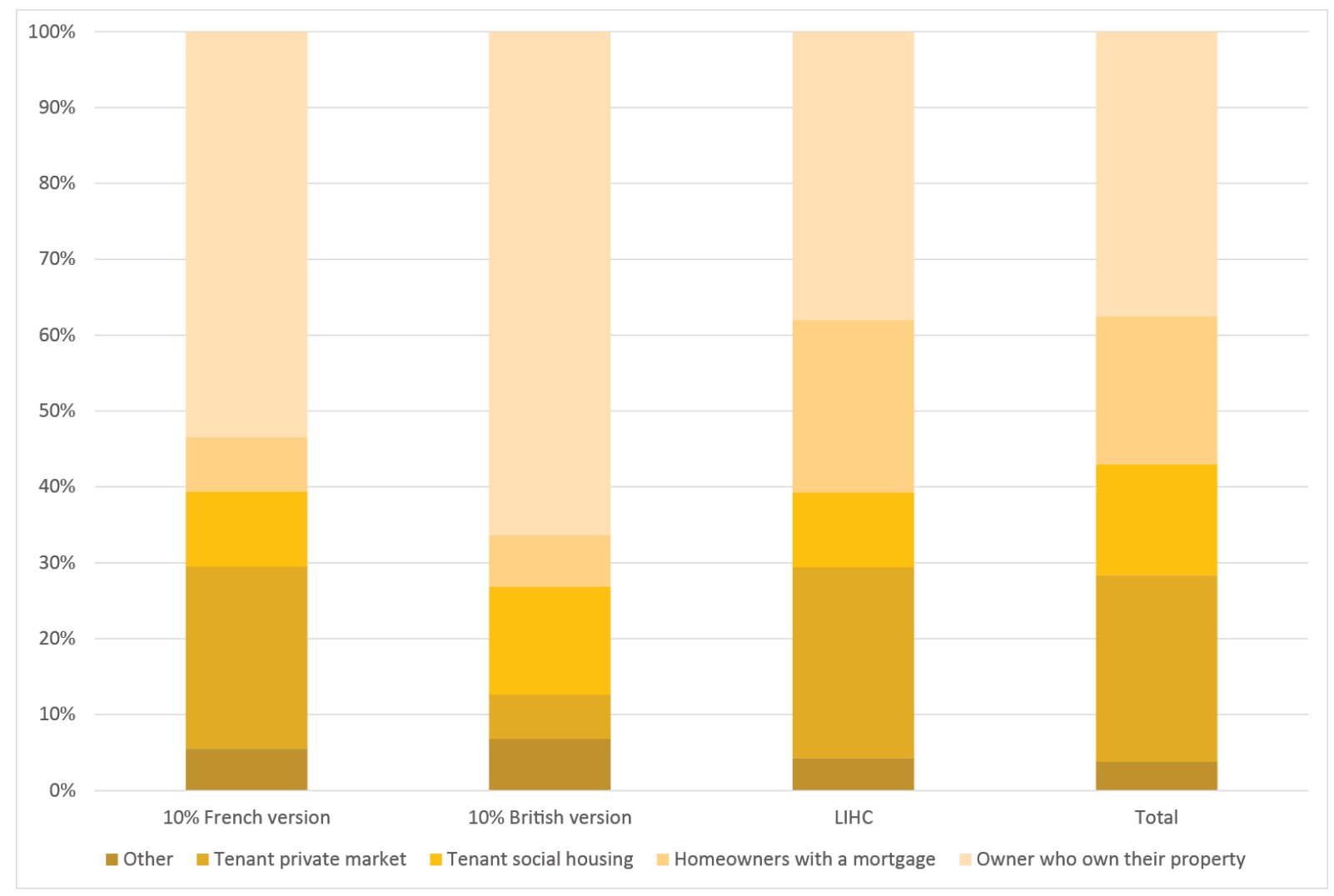

Figure 5: Representation by occupancy status. Source: authors.

Our results cannot be directly compared to those obtained in England, since there is no detailed analysis available based on 2006 data. However, analyses from 2011 show the same tendencies: In England, fewer households are found to be in fuel poverty with the LIHC indicator than with the $10 \%$ indicator (10.9\% as compared to $14.6 \%)$. When it comes to household characteristics, there are also fewer households in higher income classes identified to be fuel poor with the LIHC indicator compared to the $10 \%$ indicator. Concerning household composition, as in France, more couples with children and more single parents are fuel poor under the LIHC indicator. Tenure cannot be directly compared, since the categories used in France and England are not the same (DECC 2013a, 2013b).

The analyses reveal that the indicators do not differ much in terms of how many households are considered to be fuel poor, but much more so when it comes to finding out who is fuel poor. While the results of the French and the British versions of the $10 \%$ indicator are similar, 
the discrepancy with the LIHC indicator is more pronounced. We observe that the results for the LIHC indicator reflect several elements that characterize this approach, such as the deduction of housing costs, the introduction of relative thresholds, and the equivalisation of income. Therefore, by being aware of the principles underlying each indicator, it is possible to identify and interpret the way in which each indicator responds to its own particular logic.

Our in-depth analyses have been focused on the two most prevalent and widely discussed indicators. However, even this limited comparison illustrates the complexity and difficulty of finding an adequate indicator amongst the diverse variants and possibilities. Indeed, the annotations found in the current ONPE report indicate the reluctance, still prevalent in France, to use a specific indicator. In its 2014 report, ONPE suggests using a variety of different indicators, each one able to represent a different facet of the phenomenon (ONPE 2014, p. $55)$.

It is certainly a difficult task to find a viable and precise indicator to measure a phenomenon as complex as fuel poverty. There is also a certain risk that the choice of an indicator might be guided by the desire to confirm notions established by previously used indicators. This means, for example, that once a certain population is identified as being prone to fuel poverty, the (new) indicator would be expected to confirm these results. A more promising approach would be to give some thought to an appropriate definition of fuel poverty and only then choose an indicator that would work with the required criteria.

\section{Conclusions and policy implications}

The primary research question that motivated this article was whether it is possible to transfer fuel poverty indicators based on energy requirements, to countries with limited data availability. Given the possibility of a transfer, the second task was to carry out a case study by applying the indicators to the French context and comparing the results. 
After outlining the main principles of the selected indicators, we present an approach to estimate energy requirements in France and, in order to test the viability of the data, we carry out a case study on fuel poverty in France. Even though there have been previous attempts to apply the $10 \%$ and the LIHC indicators in France, this was with real consumption data. In this study we present, for the first time, results that are obtained when energy requirements are used, as proposed in the original version of these indicators. The results validate our approach, and correspond to the expectations for each indicator. We find that the LIHC indicator identifies slightly fewer households to be in fuel poverty than the British version of the $10 \%$ indicator (10\% versus $11 \%$ ) for 2006. Furthermore, with regard to the number of households identified, the LIHC indicator is less sensitive to energy price fluctuations, while the fuel poverty gap reflects price changes and, therefore, increases between 2006 and 2013. The LIHC indicator attenuates energy price sensibility and responds to the perception that energy price fluctuations may have a cyclical impact on the energy burden (proportion between energy costs and income) of the population as a whole. The price increase should not, by itself, be considered to impact fuel poverty as a structural problem (that is defined as the overlap of energy prices, energy efficiency and income).

Even though in quantitative terms, the differences between the indicators are negligible, they yield quite different results in qualitative terms. This means that the overlap of fuel poor households identified by each indicator is very limited (35\% of identical households), and that the characteristics of households vary considerably from one indicator to another. For example, the results indicate that the LIHC indicator detects more low-income households, more families and more tenants and homeowners with a mortgage than the $10 \%$ indicator. For other variables, such as date of construction of the dwelling and energy type, fewer differences exist. The divergence between the two indicators can be explained by the use of relative thresholds, the deduction of housing costs and equivalisation under the LIHC indicator. 
In France, where the choice of an adequate indicator is currently in discussion, an understanding of the workings of each indicator and the way in which it represents the affected population is crucial to the decision process. However, even more importantly, this process should be guided by a careful consideration of what is believed to constitute fuel poverty in the first place. Only then can the way in which each indicator describes the phenomenon be best employed.

The insights from our case study may be instructive for countries lacking the detailed data to assess fuel poverty. The robustness of approaches that rely on less detailed data could be validated by applying our method to countries with similar data restrictions. In addition, further research should review our method for the estimate of energy requirements and compare it to results obtained by using the more detailed data on building characteristics (such as Phébus for France) that was not yet available at the time of writing this article (SOes 2013)

\section{References}

Anderson, B. R., Chapman, P. R., Cutland, N. G., Dickson, C. M., Henderson, G., Henderson, J. H., Iles, P. J., Kosmina, L., Shorrock, L. D., 2002. BREDEM-12. Model description.

Bafoil, F., Fodor, F., Roux, D. L., 2014. Accès à l'énergie en Europe. Les précaires invisibles. Paris: Presses de Sciences Po.

Bazilian, M., Nakhooda, S., Van de Graaf, T., 2014. Energy governance and poverty, Energy Research \& Social Science, 1, pp. 217-225.

Bickerstaff, K., Walker, G., Bulkeley, H., 2013. Energy justice in a changing climate: social equity and low-carbon energy. New York: Zed Books.

Boardman, B., 1991. Fuel Poverty: From Cold Homes to Affordable Warmth. London: John Wiley and Sons.

Boardman, B., 2010. Fixing fuel poverty. Challenges and solutions. London, Sterling: earthscan. 
Boardman, B., 2012. Fuel poverty synthesis: Lessons learnt, actions needed, Energy Policy, 49, pp. 143-148.

Bouzarovski, S., Petrova, S., Sarlamanov, R., 2012. Energy poverty policies in the EU: A critical perspective, Energy Policy, 49, pp. 76-82.

BRE, 2011. The Government's Standard Assessment Procedure for Energy Rating of Dwellings. SAP 2009. Garston.

Brunner, K.-M., Spitzer, M., Christanell, A., 2011. NELA - nachhaltiger Energieverbrauch und Lebensstile in armen und armutsgefährdeten Haushalten. Wirtschaftsuniversität Wien. Wien.

Ceren (Centre d'études et de recherches économiques sur l'énergie), 2011. Suivi du parc et des consommations d'énergie. Ceren. Paris.

De Quero, A., Lapostolet, B., 2009. Groupe de travail: Précarité énergétique. Plan Bâtiment Grenelle. Paris.

DECC (Department of Energy and Climate Change), 2010. Fuel Poverty Methodology Handbook. London.

DECC (Department of Energy and Climate Change), 2013a. Detailed Tables England 2011. 10 per cent measure. London.

DECC (Department of Energy and Climate Change), 2013b. Detailed Tables England 2011. Low Income High Costs (LIHC) Indicator. London.

Devalière, I., Briat, P., Arnault, S., 2011. La précarité énergétique : avoir froid ou dépenser trop pour se chauffer. INSEE. Paris.

Falkner, R., 2014. Global environmental politics and energy: Mapping the research agenda, Energy Research \& Social Science, 1, pp. 188-197.

Farrell, N., Lyons, S., 2015. Who should pay for renewable energy? Comparing the household impacts of different policy mechanisms in Ireland, Energy Research \& Social Science, 7, pp. 31-42.

Gawel, E., Bretschneider, W., 2014. The affordability of water and energy pricing: the case of Germany. In T. Fitzpatrick (Ed.), International Handbook on Social Policy and the Environment. Cheltenham: Edward Elgar Publishing.

Goldthau, A., 2014. Rethinking the governance of energy infrastructure: Scale, decentralization and polycentrism, Energy Research \& Social Science, 1, pp. 134-140.

Grösche, P., Schröder, C., 2011. On the redistributive effects of Germany's feed-in tariff. ChristianAlbrechts-Universität Kiel, Department of Economics. 
Harrington, B., Heyman, B., Merleau-Ponty, N., Stockton, H., Ritchie, N., Heyman, A., 2005. Keeping warm and staying well: findings from the qualitative arm of the Warm Homes Project, Health and Social Care in the Community 13(3), pp. 259-267.

Healy, J. D., Clinch, J. P., 2002. Fuel poverty, thermal comfort and occupancy: results of a national household-survey in Ireland, Applied Energy, 73(3-4), pp. 329-343.

Heindl, P., 2015. Measuring Fuel Poverty: General Considerations and Application to German Household Data, FinanzArchiv / Public Finance Analysis, 71 (2), pp. 178-215.

Heindl, P., Schuessler, R., 2015. Dynamic properties of energy affordability measures, Energy Policy, 86, pp. 123-132.

Hills, J., 2011. Fuel poverty. The problem and its measurement. Interim Report of the Fuel Poverty Review. London School of Economics. Centre for analysis of social exclusion. London.

Hills, J., 2012. Getting the measure of fuel poverty. Final Report of the Fuel Poverty Review. London School of Economics. Centre for analysis of social exclusion. London.

Insee, 2014. Les niveaux de vie en 2012. Paris.

Isherwood, B., Hancock, R., 1979. Household Expenditure on Fuel: Distributional Aspects. Economic Adviser's Office. London.

Kopatz, M., Kettler, C., Gundlach, K., Preute, M., Schaller, S., 2013. Energiewende. Aber fair! Wie sich die Energiezukunft sozial tragfähig gestalten lässt. München: oekom.

Laurent, É., 2011. Issues in environmental justice within the European Union, Ecological Economics, 70(11), pp. 1846-1853.

Liddell, C., Morris, C., McKenzie, S. J. P., Rae, G., 2012. Measuring and monitoring fuel poverty in the UK: National and regional perspectives, Energy Policy, 49, pp. 27-32.

Liddle, R., Latham, S., 2009. How can the response to climate change be socially just? . In A. Giddens, S. Latham R. Liddle (Eds.), Building a low-carbon future: The politics of climate change. London: Policy Network.

MECSL (Ministère de l'emploi, de la cohésion sociale et du logement) 2006. Arrêté du 9 novembre 2006 portant approbation de diverses méthodes de calcul pour le diagnostic de performance énergétique en France métropolitaine. Paris.

Middlemiss, L., Gillard, R., 2015. Fuel poverty from the bottom-up: Characterising household energy vulnerability through the lived experience of the fuel poor, Energy Research \& Social Science, 6, pp. 146-154. 
Moore, R., 2011. The Hills fuel poverty review proposal for a new definition of fuel poverty: an analysis. Consumer Focus.

Moore, R., 2012. Definitions of fuel poverty: Implications for policy, Energy Policy, 49, pp. 19-26.

ONPE (Observatoire National de la Précarité Energétique), 2014. Premier raport de l'ONPE. Définitions, indicateurs, premiers résultats et recommandations. Rapport détaillé. Paris.

Preston, I., White, V., Guertler, P., 2010. Distributional impacts of UK Climate Change Policies. Final report to the eaga Charitable Trust. Centre for Sustainable Energy; Association for the Conservation of Energy.

RAPPEL (Réseau d'Acteurs Précarité - Energie - Logement), 2012. Compte-rendu de la $3^{\text {ème }}$ rencontre d'experts du RAPPEL. Enquêtes statistiques : construction, déroulé, analyse, limites.

Schaffrin, A., 2013. Who pays for climate mitigation? An empirical investigation on the distributional effects of climate policy in the housing sector, Energy and Buildings, 59, pp. 265-272.

Schiellerup, P., Chiavari, J., Bauler, T., Grancagnolo, M., 2009. Climate change mitigation policies and social justice in Europe. An exploration of potential conflicts and synergies. Discussion paper. King Baudouin Foundation.

SOeS (Service de l'observation et des statistiques), 2013. L'enquête sur la Performance de l'Habitat, Équipements, Besoins et USages de l'énergie (Phébus). Paris.

SOeS (Service de l'observation et des statistiques), 2014. Base de données Pégase. Ministère de l'Écologie, du Développement Durable et de l'Énergie. Paris.

Sovacool, B. K., 2013. Energy \& ethics: justice and the global energy challenge. Energy, climate, and the environment series. Basingstoke, UK/New York, USA: Palgrave Macmillan.

Sovacool, B. K., Dworkin, M. H., 2014. Global energy justice: problems, principles, and practices. Cambridge: Cambridge University Press.

Sovacool, B. K., Sidortsov, R. V., Jones, B. R., 2014. Energy security, equality, and justice. London: Routledge.

Stockton, H., Campbell, R., 2011. Time to reconsider UK energy and fuel poverty policies? National Energy Action, Joseph Rowntree Foundation. York.

Tews, K., 2013. Energiearmut definieren, identifizieren und bekämpfen - Eine Herausforderung der sozialverträglichen Gestaltung der Energiewende. Vorschlag für eine Problemdefinition und Diskussion des Maßnahmenportfolios. FFU-Report 04-2013. Freie Universität Berlin. Forschungszentrum für Umweltpolitik. Berlin.

Thomson, H., Snell, C., 2013. Quantifying the prevalence of fuel poverty across the European Union, Energy Policy, 52, pp. 563-572. 
Ürge-Vorsatz, D., Tirado Herrero, S., 2012. Building synergies between climate change mitigation and energy poverty alleviation, Energy Policy, 49, pp. 83-90.

Waddams Price, C., Brazier, K., Wang, W., 2012. Objective and subjective measures of fuel poverty, Energy Policy, 49, pp. 33-39.

Walker, G., Day, R., 2012. Fuel poverty as injustice: Integrating distribution, recognition and procedure in the struggle for affordable warmth, Energy Policy, 49, pp. 69-75.

Walker, R., Liddell, C., McKenzie, P., Morris, C., Lagdon, S., 2014. Fuel poverty in Northern Ireland: Humanizing the plight of vulnerable households, Energy Research \& Social Science, 4, pp. 89-99. 